\title{
Ван Ювэй
}

ЭДИСОН ДЕНИСОВ КАК КОМПОЗИТОР ТЕАТРА НА ТАГАНКЕ: ВЗАИМОСВЯЗЬ ПРИКЛАДНОГО И "ЧИСТОГО" ТВОРЧЕСТВА

Статья посвящена проблеме взаимодействия музыки и сценического действия в театре. Проблема анализируется на примере сотрудничества композитора Эдисона Денисова с режиссером Юрием Любимовым и возглавляемым им Театром на Таганке. В статье обобщены сведения о спектаклях с музыкой Денисова в этом театре. Рассматривается восприятие музыки для театра как специальной сферы творчества. Как пример воздействия театральной музыки на "чистое" творчество Денисова рассмотрены его "Голубая тетрадь" на стихи Д. Хармса и А. Введенского и "Пароход плывет мимо пристани".

Адрес статьи: www.gramota.net/materials/9/2019/11/65.html

\section{Источник}

\section{Манускрипт}

Тамбов: Грамота, 2019. Том 12. Выпуск 11. С. 346-350. ISSN 2618-9690.

Адрес журнала: www.gramota.net/editions/9.html

Содержание данного номера журнала: www.gramota.net/materials/9/2019/11/

\section{() Издательство "Грамота"}

Информация о возможности публикации статей в журнале размещена на Интернет сайте издательства: www.gramota.net Вопросы, связанные с публикациями научных материалов, редакция просит направлять на адрес: hist@gramota.net 
Статья посвящена проблеме взаимодействия музыки и сценического действия в театре. Проблема анализируется на примере сотрудничества композитора Эдисона Денисова с режиссером Юрием Любимовым и возглавляемым им Театром на Таганке. В статье обобщены сведения о спектаклях с музыкой Денисова в этом театре. Рассматривается восприятие музыки для театра как специальной сферы творчества. Как пример воздействия театральной музыки на «чистое» творчество Денисова рассмотрены его «Голубая тетрадь» на стихи Д. Хармса и А. Введенского и «Пароход пльвет мимо пристани».

Ключевые слова и фразы: Эдисон Денисов; Юрий Любимов; музыка; театр; полистилистика; «Голубая тетрадь»; «Пароход плывет мимо пристани».

\section{Ван Ювэй}

Московский государственный университет имени М. В. Ломоносова 670308930@qq.com

\section{ЭДИСОН ДЕНИСОВ КАК КОМПОЗИТОР ТЕАТРА НА ТАГАНКЕ: ВЗАИМОСВЯЗЬ ПРИКЛАДНОГО И «ЧИСТОГО» ТВОРЧЕСТВА}

Композитор Эдисон Денисов работал как театральный композитор на протяжении тридцати лет, с середины 1960-х до середины 1990-х годов. Его деятельность в этой сфере была постоянно связана с режиссером Юрием Любимовым и Театром на Таганке. Творческий союз двух гениальных представителей русского искусства, Любимова и Денисова, представляет собой уникальное явление в истории отечественной культуры второй половины XX века. Вместе с тем не существует ни одного научного исследования, специально посвященного этому явлению. Этим определяется актуальность нашей статьи. Нашими задачами было обобщить сведения из различных источников о работе Денисова в Театре на Таганке (1), раскрыть роль музыки в спектаклях Любимова (2) и специфику работы композитора в его театре (3). Цель статьи заключалась в выявлении влияния работы Денисова в театре на его «чистое» творчество. Вопрос влияния театральной сферы его композиторской деятельности на «чистое» творчество до сих пор не являлся предметом исследования в научных статьях. Позиция самого композитора, строго разграничивавшего эти области своей деятельности, не способствовала появлению исследований на эту тему. Однако, по нашему мнению, в наследии Денисова можно найти несколько произведений, где театральность проникает в его музыку, существующую вне театра. Таковыми являются вокально-инструментальный цикл «Голубая тетрадь» на слова Д. Хармса и А. Введенского и пьеса для шумового оркестра «Пароход плывет мимо пристани». Научное обоснование влияния театрального опыта на «чистое» творчество Денисова определяет научную новизну нашего исследования.

Работа Эдисона Денисова в театре продолжалась на протяжении всей его творческой жизни. Среди соавторов композитора были выдающиеся режиссеры: Юрий Любимов, Игорь Кваша, Александр Калягин и другие. Спектакли с его музыкой шли в нескольких театрах: в Театре на Таганке, «Современнике», Московском академическом театре имени Вл. Маяковского, Московском драматическом театре имени М. Н. Ермоловой. В итоге Денисовым была написана музыка более чем к тридцати спектаклям.

Сотрудничество Денисова и Любимова продолжалось около тридцати лет: от первого совместного спектакля «Послушайте!» (по В. В. Маяковскому), поставленного в Театре на Таганке в 1967 году, до последнего, «Подросток» (по Ф. М. Достоевскому). Премьера «Подростка» состоялась 23 апреля 1996 года за полгода до смерти композитора. В итоге для Театра на Таганке оказались созданными около трети всех театральных работ Денисова. Самыми известными, кроме упомянутых, стали «Мастер и Маргарита» (1977, по роману Михаила Булгакова), «Преступление и наказание» (1979, по роману Федора Достоевского), «Дом на набережной» (1980, по повести Юрия Трифонова), «Три сестры» (1981, по пьесе Антона Чехова), «Медея» (1995, по трагедии Еврипида).

Денисов называл Юрия Любимова одним из близких друзей, оказавших на него большое влияние «в профессиональном и общечеловеческом отношении» $[10$, с. 46]. Их многолетнее сотрудничество имело для композитора значение, выходящее за пределы создания музыки к спектаклям. В беседах с Дмитрием Шульгиным он разъяснял: «Работа в театре на Таганке мне и помогла понять, что такое театр, что такое театральная драматургия и каково должно быть вообще настоящее соотношение в театре слова, действия, света, декораций, музыки. Это была для меня самая настоящая школа» [Там же, с. 47].

Любимов искал соавторов, творчество которых соответствовало бы экспериментальному характеру его спектаклей и духу эстетики в целом. Приглашение к сотрудничеству Денисова, во второй половине 1960-х имевшего репутацию одного из самых ярких молодых композиторов-авангардистов, можно воспринять как проявление общей художественной политики Театра на Таганке и его режиссера.

Что особенно важно для нас в связи с взаимодействием Любимова и Денисова, - стиль Театра на Таганке отличала особая музыкальность. Этот факт подтвержден рецензиями влиятельных критиков. В одной из первых рецензий на спектакль «Добрый человек из Сезуана» отмечалось, например, что исполнительница главной роли Шен Те, Шуи Та Зинаида Славина «прозаические фразы Брехта» произносила «как стихотворные» [1]: она придавала чтению прозы периодичность ритмических и интонационных акцентов, подобную стихам. 
Тонкий музыкальный слух, ощущение ритма, мелодичность, напевность произнесения текста (в том числе и прозаического) отличали и других актеров этого театра, например, Владимира Высоцкого, Аллу Демидову, Валерия Золотухина, Вениамина Смехова.

Ощущение музыкальности речи актеров было результатом тщательно продуманной работы режиссера. Во время репетиций Любимов воспитывал в актерах чувство ритма, приучал их к счету про себя, наподобие того, как это делают музыканты. Режиссер использовал и другой прием, применяемый и в работе певцов. Во время репетиций он просил актеров вслушиваться в музыку на протяжении 5-6 секунд, до того как они начнут говорить: «Когда музыка войдет в тебя - ты начнешь продолжать дальше» [3, с. 13]. Этот прием давал актерам время на то, чтобы по-настоящему услышать музыку и настроиться на нее. По словам Любимова, он был необходим, чтобы «действительно прошла музыка через него [актера] и стала ему нужна» [Там же]. В качестве аналогии можно назвать умение певцов «войти» в музыку, вслушиваясь в инструментальные вступления и проигрыши между вокальными фразами.

Любимов с гордостью вспоминал в мемуарах отзыв Денисова о музыке спектаклей Театра на Таганке. Под впечатлением от выступления нескольких актеров (в том числе Золотухина) композитор «сказал, что он не ожидал, что так артисты могут петь» [5, с. 556]. В мемуарах Любимов говорит, что для него слова Денисова важны не только как «комплимент». Важно, «что это целая линия театра, и она дает особый колорит, лицо театру» [Там же].

Денисов не раз говорил о музыкальности спектаклей Театра на Таганке. Приведем в подтверждение этому цитаты из его воспоминаний: «Любимов сказал мне: “Эдисон! Вынь из «Трех сестер» музыку - спектакля нет, исчез, разрушен полностью”. Для Любимова музыка в спектакле бывает иногда даже более важной, чем игра отдельных актеров. Это сердце его драматургии» [10, с. 16]. И, наконец, суммирующее высказывание композитора: Любимов - «он один из немногих, кто наиболее точно чувствует, как музыка может и должна работать в спектакле... он удивительно точно её обыгрывает...» [Там же, с. 411].

Любимов искал среди композиторов соавторов, творчество которых соответствовало бы экспериментальному характеру его спектаклей. Не случайно в 1960-1980-е годы в качестве авторов музыки в Театре на Таганке одновременно с Денисовым работали многие современные композиторы. Среди них: Николай Каретников (спектакль «Десять дней, которые потрясли мир», 1965), Юрий Буцко («Пугачев», 1967; «Мать», 1969; «Что делать?», 1970; «А зори здесь тихие», «Гамлет», оба - 1971), Андрей Волконский («Тартюф», 1968), Николай Сидельников («Бенефис», 1973; «Деревянные кони», 1974), София Губайдулина («Перекресток», 1977), Альфред Шнитке («Ревизская сказка», 1978; «Турандот, или Конгресс обелителей», 1979; «Пир во время чумы», 1989) и другие. Любимов приглашал к сотрудничеству даже западноевропейских композиторовавангардистов, таких как Луиджи Ноно (спектакль «Пристегните ремни», 1975).

С именем Луиджи Ноно был связан примечательный эпизод в творческих биографиях Любимова и Денисова - их совместная работа над премьерой оперы Ноно «Под жарким солнцем любви» (“Al gran sole carico d'amore"). Вскоре после выпуска спектакля «Пристегните ремни» в Театре на Таганке Ноно пригласил Любимова в качестве режиссера в Италию на постановку в «Ла Скала» своей оперы. Подготовка ее премьеры стала для режиссера очень сложной по нескольким причинам: он в первый раз ставил оперу, постановка осуществлялась в зарубежном театре. Но, самое главное, у него было всего два месяца на работу, и до приезда в Италию он не знал все произведение целиком.

В этой трудной ситуации Любимов позвал на помощь именно Денисова. По словам режиссера, Денисов «лист за листом» расшифровывал для него оркестровую партитуру, «которая местами оказывалась необычайно сложна» [5, с. 482]. В некоторых эпизодах оперы, особенно трудных для восприятия, композитор играл партитуру, стараясь передать общий «характер того или иного отрывка» [Там же]. Если же воспроизвести музыку на рояле оказывалось невозможным, он давал режиссеру «послушать другое, уже записанное на пластинку произведение Ноно, похожее на интересующий... отрывок» [Там же]. В итоге премьера оперы Ноно в «Ла Скала» прошла успешно, свидетельством чему стали показы спектакля и в следующем сезоне 1975/1976 годов. Приглашение Любимовым Денисова для совместной работы свидетельствовало не только о большом доверии к нему как к профессионалу, но и о его репутации как эрудита и знатока современной музыки.

Сотрудничество с Театром на Таганке во многом сформировало дружеский и творческий круг Денисова. Среди его близких друзей было несколько ведущих актеров театра, например, Алла Демидова и Вениамин Смехов [3; 9]. В этом смысле не случайно, например, участие Смехова (в качестве чтеца) в первом исполнении и записи «Голубой тетради» (1985) Денисова на слова А. Введенского и Д. Хармса. Делая первые опыты в качестве режиссера, Смехов в свою очередь приглашал Денисова к совместной работе как композитора. Первый из их совместных кинофильмов («Волшебник из Шираза») вышел на экраны в 1972 году.

Из сказанного очевидна интенсивность работы Денисова в области музыки для театра. Вместе с тем отношение Денисова к этой сфере творчества было неоднозначным. В его представлении музыка для театра не имела самостоятельной ценности и значения, являясь частью спектакля. Необычайно высоко ценя спектакли Любимова, с большим интересом работая с ним, композитор воспринимал свою музыку в них лишь как один из элементов художественного целого.

В этом смысле характерно, что Денисов никогда не перерабатывал свою музыку для театра (как и музыку для кино) в самостоятельные сочинения. Он в принципе не рассматривал возможность ее существования как «чистой» музыки - вне контекста театральной сцены. Этим Денисов отличался, например, от своего сверстника и друга Альфреда Шнитке. (Как известно, Шнитке создал ряд произведений, использовав в них свою музыку для театра.) Театральная музыка Денисова была исполнена в концерте лишь один раз - в Лондоне в декабре 1980 года [7, с. 112]. Инициатором этого исполнения стал дирижер Геннадий Рождественский. 
Позднее композитор жалел о том, что разрешил такой эксперимент: «Это была большая моя ошибка: она, эта музыка, прекрасно работает в театре (и все это знают, и Любимов мне сто раз повторял, что без этой музыки спектакль не существует) - это часть спектакля; но вырванная из него, сыгранная отдельно, она не имеет того смысла, который в ней заложен, того, ради чего она была написана. Это не музыка для концерта. Вот в чем разница...» [10, с. 131]. Характерно, что исполненную в Лондоне симфоническую сюиту из музыки к знаменитому спектаклю Театра на Таганке «Мастер и Маргарита» по роману Булгакова составил не сам Денисов, а Рождественский [Там же].

Денисов воспринимал сочинение прикладной театральной музыки как особую сферу деятельности, отделяя ее от «чистого» творчества. Одной из главных причин такого разграничения в представлении композитора была эклектика как органическое качество театральной музыки. Введение в спектакли цитат из музыки разных времен и стилей является общераспространенной практикой. И Денисов шел на это по требованию режиссера, - ради создания атмосферы времени и для расстановки смысловых акцентов в действии.

Воспринимая введение музыкальных цитат в сопровождение театрального действия как необходимость, композитор вместе с тем избегал приемов звукового коллажа в своей «чистой» музыке. По его высказываниям понятно, что включение цитат в «чистую» музыку он считал недостатком: «Введение любой цитаты должно быть оправданно и смыслово и музыкально. Сейчас на этих цитатах все подряд спекулируют» [7, с. 43].

Эта позиция во многом определяла его отношение к полистилистике - технике, предусматривающей объединение в одном сочинении различных стилистических элементов. Важно, что полистилистика в музыке Шнитке воспринималась Денисовым в какой-то мере как проявление влияния работы в театре и кино. Это влияние Денисов оценивал как отрицательное. В диалогах с Шульгиным он говорил: «Альфред [Шнитке] слишком много работал в кино и театре, и это, естественно, оказало большое влияние на его последующие сочинения. <..> И это [полистилистика] то, что я меньше всего люблю в Альфреде. Я люблю в нем совсем другое. А это направление мне вообще в музыке антипатично и иногда даже неприятно у абсолютно всех композиторов» [10, с. 55]. Продолжая развивать тему, композитор добавлял эмоционально: «Это просто абсолютно бессмысленное, с моей точки зрения, направление. Абсолютно! И к тому же в определенном отношении - спекулятивное. <..> Оно работает на не очень хороших качествах публики и, прежде всего, на элементе некоторой её необразованности» [Там же].

В сказанном проявляется эстетическое «кредо» Денисова - композитора, для которого чрезвычайно важным было сохранение единства авторского стиля. Создание «точного (и индивидуального) звукового мира» [7, с. 35] принцип, который композитор последовательно воплощал от самых первых до последних своих сочинений. Возможно, в стремлении строго соблюдать творческие принципы сказалось системное мышление Денисоваматематика. (Напомним, что до поступления в консерваторию он закончил физико-математический факультет Томского государственного университета.)

Из сказанного становится понятной позиция композитора по отношению к собственной прикладной и «чистой» музыке - желание строго разграничивать эти сферы творчества. И все же в наследии Денисова можно найти сочинения, компромиссные с этой точки зрения. Творческая гибкость давала яркие, неожиданные на фоне общей цельной картины творчества Денисова результаты.

Проявления влияния театра в творчестве Денисова есть, например, в упомянутой выше «Голубой тетради» на слова А. Введенского и Д. Хармса. Стиль этого сочинения кратко, но выразительно охарактеризован Ю. Н. Холоповым как «фантастическое сочетание изысканной красоты утонченных звучаний и абсурдистского текста» [9, с. 159]. В ней парадоксальные тексты Хармса в исполнении чтеца соединяются с лирическими стихами Введенского в партии сопрано. В действие на сцене включаются также инструменталисты, взаимодействующие с чтецом и певицей. Характерно, что на протяжении цикла чтец и певица почти не выступают вместе: они солируют в разных номерах, образуя как бы параллельное действие. Единственным исключением является пятый номер цикла с характерным названием «Тюк». В нем участвуют чтец, певица и четыре инструменталиста. В названии номера отражен один из главных звуковых образов пьесы - «удар колуном по полену». Его звук изображается с помощью удара молотком по струнам внутри рояля (Рiano II). В итоге получается короткий, странный, как бы надтреснутый звук.

Абсурдно само действие, описанное ремаркой в нотах: «Ольга Петровна [певица] колет дрова. При каждом ударе с носа Ольги Петровны соскакивает пенсне. Евдоким Осипович сидит в кресле и курит» [4, с. 35]. По сюжету пьесы, Евдоким Осипович не только «сидит и курит», но наблюдает за Ольгой Петровной, сопровождая каждый ее удар топором по полену звукоизобразительным словом «Тюк!». Возмущение Ольги Петровны растет. На ее многократные просьбы «не говорить слова “тюк”» Евдоким Осипович не реагирует. Конфликт между героями находит выход в кульминации - завершении номера. Герои замолкают: «Ольга Петровна стоит неподвижно с открытым ртом и смотрит на удаляющегося Евдокима Осиповича». Немая сцена сопровождается соло пианистов, скрипача и виолончелиста. Пианисты по предписанию композитора «скребут ногтями по обмотке басовых струн», скрипач и виолончелист играют смычками «на обратной стороне грифа» инструмента. На слух соло инструменталистов производит впечатление неприятного скрежета. В рамках вокального цикла для певицы, чтеца и ансамбля инструменталистов этот номер воспринимается как эксцентричная кульминация. Но, на наш взгляд, его можно было бы представить и как сцену драматического спектакля. Этому впечатлению способствует, в частности, то, что певица здесь не поет, а говорит.

Другим примером воплощения театральности в «чистом» творчестве Денисова является музыка для шумового оркестра, посвященная выдающемуся исполнителю на ударных инструментах Марку Пекарскому «Пароход плывет мимо пристани» (1986). Название пьесы представляет собой цитату из русской частушки периода Гражданской войны 1918-1922 годов: «Пароход плывет / Мимо пристани. / Будем рыб кормить / 
Коммунистами» [6, с. 25]. О сотрудничестве Пекарского с композиторами-авангардистами, в том числе Денисовым, см.: [8, с. 831-832].

Начало пьесы, выдержанное в размеренном ритме, создает образ приближающегося к пристани парохода. Позже на него накладывается наигрыш гармошки в духе народных городских песен. В изысканное плетение ритмов ударных инструментов врываются мелодия популярной советской песни «Эх, хорошо в стране советской жить» (композитор Исаак Дунаевский), «Марш авиаторов» Ю. А. Хайта, свист (свисток милиционера) и революционный марш «Смело товарищи, в ногу!». Постепенно темы песен искажаются, вплетаются в хроматическое плетение фактуры, характерное для авторского стиля Денисова. Вся пьеса заканчивается ударом, который производит впечатление взрыва на пароходе. Эта музыка, в целом не типичная для Денисова, в какойто мере была подсказана совместной работой Любимова и Денисова над спектаклем «Дом на набережной».

По свидетельству композитора, идея цитирования песни Дунаевского «Эх, хорошо в стране советской жить» родилась непосредственно во время работы с Любимовым. Во время репетиций спектакля «Дом на набережной» они искали музыку, которая могла бы передать атмосферу советских 1930-х годов. Денисов цитирует в своих воспоминаниях слова Любимова: «Эдисон! Здесь обязательно нужна краска времени, краска эпохи... Дай мне её музыкальный символ...» [10, с. 351]. В поисках такого символа композитор вспомнил популярную в 1930-х годах песню «Эх, хорошо в стране советской жить». Она была введена в спектакль как резко контрастный фон для событий, связанных с политическими репрессиями: «Любимов страшно обрадовался: “Эдисон, - говорит, - это замечательная идея: пионеры на набережной... они будут петь «Эх, хорошо в стране советской жить» и тут же кого-то будут арестовывать и сажать”» [Там же]. Контраст песни Дунаевского происходящему на сцене оказался даже сильнее, чем рассчитывали авторы спектакля. Государственная комиссия, принимавшая «Дом на набережной», запретила воспроизведение песни.

Но через несколько лет, получив заказ на пьесу для ударных от Марка Пекарского, Денисов вспомнил о ней. Так возникла пьеса «Пароход плывет мимо пристани», звуковой образ которой описывался выше. Денисов и Пекарский не ограничились ее концертным исполнением, создав своего рода театральную инсценировку. Их совместными усилиями на сцене Института им. Гнесиных было разыграно целое представление. В этом представлении главную роль играл отряд пионеров, которые выстраивали «разные гимнастические пирамиды», ходили по сцене строем, крутили в руках «школьные линейки, изображая пропеллеры первых советских самолетов» [Там же]. Последнее из описанных действий сопровождалось в музыке цитатой из «Марша авиаторов» («Всё выше, и выше, и выше»).

Но главная роль в импровизированном спектакле на основе пьесы для ударных принадлежала песне Дунаевского «Эх, хорошо в стране советской жить». Марк Пекарский посадил за рояль в зале Института им. Гнесиных «очень хорошего музыканта, но такую характерную по внешности, как бы тапершу из немого кино, старую и полную еврейку Раису Барановскую, которая всё время играла на нарочно расстроенном пианино музыку “Эх, хорошо в стране советской жить”. И это было прекрасно» [Там же]. Публика восприняла «весь спектакль просто со страшным энтузиазмом, с каким-то даже рёвом...» [Там же]. Премьера представления «Пароход плывет мимо пристани» состоялась 1 апреля 1987 года. Его замысел был ассоциативно связан со спектаклем Любимова, а песня Дунаевского стала непосредственным символом этой связи.

Рассмотренные в статье произведения Денисова находятся на грани «чистой» и прикладной музыки. Стилистически они пересекаются с театральными работами композитора. В первом случае («Голубая тетрадь») этому способствуют участие чтеца (драматического актера) и яркая звукоизобразительная трактовка инструментального ансамбля. Во втором («Пароход плывет мимо пристани») - звукоизобразительность и, в дополнение к ней, - цитатность. Возникновение этих сочинений во многом обязано опыту работы композитора в театре. Они являются в творчестве Денисова редким, но ярким исключением, раскрывающим образ композитора в необычном ракурсе.

Подводя итог сказанному в статье, отметим уникальность многолетнего творческого союза Юрия Любимова и Эдисона Денисова. Этот союз основывался, с одной стороны, на музыкальности режиссуры Любимова и на особых музыкальных методах его работы с актерами, с другой, - на тонком ощущении композитором роли музыки как сопровождения театрального действия. Многолетняя практика работы в Театре на Таганке напрямую воздействовала на творчество Денисова вне театра. Именно благодаря ей возникли несколько уникальных произведений композитора - «Голубая тетрадь» и «Пароход плывет мимо пристани». Имманентно музыкальные законы развития дополнены в них воздействием театральной драматургии.

Список источников

1. Гаевский В. М. Славина // Театр. 1967. № 2. С. 75-78.

2. Григорьева Г. Мои тридцать лет с Эдисоном Денисовым. Воспоминания, документы, статьи. М.: НИЦ «Московская консерватория», 2017. $134 \mathrm{c.}$

3. Демидова А. Ностальгия - это память. М.: АСТ, 2016. 352 с.

4. Денисов Э. Голубая тетрадь. Партитура. Факсимиле с рукописи. М.: ВААП, 1984. 96 с.

5. Любимов Ю. Рассказы старого трепача: воспоминания. М.: Новости, 2001. 576 с.

6. Малков Д. Здесь, под небом чужим... // Книжное обозрение. 2017. № 25-26 (2427-2428).

7. Неизвестный Денисов. Из Записных книжек (1980/81-1986, 1995) / публ., сост., вст. ст. и коммент. В. Ценовой. М.: Композитор, 1997. 159 с.

8. Попов Л., Аркус Л. Новейшая история отечественного кино: 1986-2000: в 2-х ч.: в 7-ми т. СПб.: Сеанс, 2004. Ч. 2. Кино и контекст. Т. 6. 1992-1996. 882 с.

9. Холопов Ю. Н. Денисов Эдисон Васильевич // Творческие портреты композиторов. М.: Музыка, 1990. С. 158-159.

10. Шульгин Д. И. Признание Эдисона Денисова. По материалам бесед. М.: Композитор, 1998. 463 с. 


\title{
EDISON DENISOV AS A COMPOSER OF THE TAGANKA THEATRE: INTERRELATION OF “PURE” AND APPLIED ART
}

\author{
Wang Youwei \\ Lomonosov Moscow State University \\ 670308930@qq.com
}

\begin{abstract}
The article is devoted to the problem of interrelation of music and theatrical action. The problem is analysed by the example of creative cooperation of the composer Edison Denisov and the Taganka Theatre directed by Yuri Lyubimov. The paper summarizes information on the Taganka Theatre's performances with Denisov's music. Theatrical music is considered as a special sphere of the composer's creative work. To illustrate the influence of theatrical music on Denisov's "academic" music, his "Blue Notebook" on D. Kharms's and A. Vvedensky's poetry and the song "The Steamer Passes by the Marina" are examined.
\end{abstract}

Key words and phrases: Edison Denisov; Yuri Lyubimov; music; theatre; poly-stylistics; "Blue Notebook"; "The Steamer Passes by the Marina".

УДК $7 ; 7.01 ; 7.08$

https://doi.org/10.30853/manuscript.2019.11.66

Дата поступления рукописи: 25.07.2019

Статья посвящена изучению спектакля «Фальстаф и прини Уэльский», завершившего творческий путь М. А. Захарова (1933-2019), представителя блестящей плеяды режиссеров-шестидесятников, лидера Ленкома на протяжении четырех с половиной десятилетий и обладателя виртуозного постановочного мастерства. Предмет исследования - изучение сценической поэтики постановки. Методология исследования опирается: 1) на методы изучения поэтики художественных произведений, выработанные формальной школой литературоведения; 2) на методы реконструкиии и анализа спектакля, выработанные ленинградской (гвоздевской) школой театроведения; 3) на подходы к изучению режиссерских методологий, выработанных петербургской школой мейерхольдоведения; 4) на метод контекстуального анализа. Цель исследования - реконструкция спектакля и анализ основополагающих слагаемых его поэтики. При этом решаются задачи: 1) реконструкции спектакля; 2) определения режиссерского сюжета и способов его сложения; 3) анализа сиенографии спектакля с точки зрения организации пространства и времени; 4) выяснения композиционных принципов построения действия; 5) выявления жанровой природы постановки; 6) определения используемых в спектакле способов существования актера и прояснения смысла их применения; 7) установления места и роли спектакля в творчестве Захарова.

Ключевые слова и фразы: М. А. Захаров; «Фальстаф и принц Уэльский»; формальная школа литературоведения; поэтика; гвоздевская театроведческая школа; реконструкция спектакля; анализ спектакля; режиссерский сюжет и приемы его сложения; композиция; жанр; способ актерского существования.

Ряпосов Александр Юрьевич, к. искусствоведения

Российский институт истории искусств, г. Санкт-Петербург

alexandrryaposov@gmail.com

\section{СПЕКТАКЛЬ М. А. ЗАХАРОВА «ФАЛЬСТАФ И ПРИНЦ УЭЛЬСКИЙ» (ЛЕНКОМ, 2018): СЮЖЕТ, КОМПОЗИЦИЯ, ЖАНР, СПОСОБ АКТЕРСКОГО СУЩЕСТВОВАНИЯ}

Премьера спектакля «Фальстаф и принц Уэльский» состоялась в Московском театре имени Ленинского комсомола (Ленком) 14 апреля 2018 г. и волею судьбы оказалась завершающей сценической работой Марка Анатольевича Захарова (1933-2019), последнего представителя блестящей плеяды режиссеровшестидесятников (А. В. Эфрос, О. Н. Ефремов, Г. А. Товстоногов, Ю. П. Любимов и П. Н. Фоменко) [1], более чем четыре с половиной десятка лет стоявшего у руля одного из наиболее значимых российских театров Ленкома; классика сценического и экранного искусства, чье творчество официально включено в учебные программы российских театральных вузов; обладателя виртуозного и крайне редко встречающегося в современном театре постановочного мастерства, что признается даже теми исследователями, которые не приемлют захаровские сценические приемы и методы [12, с. 119-121].

Объектом исследования является ленкомовский спектакль «Фальстаф и принц Уэльский» в контексте сценического и экранного творчества Захарова, взятого как целое.

Предмет исследования - изучение сценической поэтики захаровской постановки.

Методология исследования опирается: 1) на методы изучения поэтики литературных произведений, выработанные формальной школой литературоведения Российского института истории искусств (РИИИ) в лице В. М. Жирмунского, В. Б. Шкловского и др. [14; 56-58] и перенесенные на изучение поэтики других художественных произведений, в первую очередь - кинематографических [55]; 2) на методы реконструкиии и анализа спектакля, выработанные ленинградской (гвоздевской) школой театроведения РИИИ и явившиеся приложением методологии формальной школы к изучению сценического искусства [6-10]; 3) на подходы к изучению режиссерских методологий, выработанные школой мейерхольдоведения Г. В. Титовой (ЛГИТМиК - 